\title{
FIFTH DISEASE IN CHILDREN LIVING IN BELÉM, BRAZIL
}

\author{
Mario F. R. de MIRANDA (1), A. C. LINHARES (2) \& J. A. SHIRLEY (3)
}

\begin{abstract}
SUMMARY
Acute sera from two children suffering from an illness with an erythematous rash were positive for $\mathrm{B} 19$ virus specific IgM antibody, as tested by a capture radioim munoassay. The first patient, a two year old boy, presented with a cutaneous rash of six days duration. the second was a four year old girl, sister of the first patient, who was examined at the same time and had a three day history of cutaneous rash.
\end{abstract}

KEY WORDS: Fifth disease: B 19; Children: Brazil.

\section{INTRODUCTION}

Human parvovirus B 19 was first found in serum of largely symptomless blood donors ${ }^{6}$ and has subsequently been associated with non-specific febrile illness ${ }^{18}$, aplastic crises in chronic haemolytic anaemias ${ }^{2.7 .9 .17}$ and acute arthritis ${ }^{15}$ 20. In addition, human parvovirus $B 19$ was shown to cause erythema infectiosum (EI) or "fifth disease", an acute exanthem of childhood".

In Belém, Brazil, "rubella-like illnesses" are seen more frequently during the first six months of the year in children and occasionally in adults. Although routine investigations are carried out for evidence of rubella, measles, arbovirus infection and other exanthematous disea ses, the aetiology remains unknown in a large proportion of cases. Because local facilities are not available, we have recently begun sending sera from such cases to England to be tested for the presence of specific IgM antibody against
B 19 virus. Our preliminary report deals with the first two cases of EI in Belem, Brazil, involving children under five years of age whose acute sera were positive for the presence of anti B 19 virus IgM antibodies.

\section{PATIENTS AND METHODS}

Both patients lived in Belém City, north Brazil, which is located in the eastern Amazon at the convergence of Guamá and Pará rivers (10" $30^{\prime} 20^{\prime \prime} \mathrm{S}, 48^{\prime \prime} 39^{\prime} 30^{\prime \prime} \mathrm{W}$ ). The climate is of tropical rain forest (Koppen) type, with a very heavy rainfall in the months of February, March and April. The annual mean temperature ranges from 24 to $28^{\circ} \mathrm{C}$, and the relative air humidity is always high, about $80 \%$ throughout the year.

The two patients attended the Dermatology Unit of the Air Force Hospital of Belém in March

(1) Hospital de Aeronautica de Belem, Unidade de Dermatologia. Belém, Pará, Brasil.

(2) Instituto Evandro Chagas, Fundação Serviços de Saúde Publica, Belém. Pará. Brasil.

(3) Regional Virus Laboratory, East Birmingham Hospital. Birmingham, UK

Address for correspondence: Dr. A. C. Linhares. Instituto Evandro Chagas. Av. Almirante Barroso. 492. Caixa Postal 1128 CEP 66050 Belem. Pará, Brazil. 
1987, suffering from an illness with an erythematous rash. The first, a two year old boy, exhibited on clinical examination, a cutaneous erup tion of six days duration. On examination there was a maculopapular rash on his face, anterior thorax and limbs; on his cheeks the erythema was diffuse, slightly raised and edematous; on his thorax and limbs a reticulate pattern was seen (Fig. 1). The second patient was a four year old girl, sister of the first patient, who was examined at the same time and had a three day history of a cutaneous rash. Except for minimal facial ery thema, the eruption showed the same pattern as described for her brother. No constitutional symptoms were recorded in either case.

During the acute phase of the illness, serum samples, faecal specimens and throat swabs were taken from each child. One month later further serum samples were obtained from both children.

As facilities were not available in our labora tory, acute sera were sent to the Rubella Depart ment, Regional Virus Laboratory, East Birmin gham Hospital, Birmingham, UK, where tests were carried out for the presence of anti-B 19 virus IgM antibodies. The method used was a capture radioimmunoassay, MACRIA, as descri bed by COHEN et $a l^{5}$.

By using standard serological procedures, paired serum samples were also tested for the presence of antibody for rubella, measles, infec tious mononucleosis, toxoplasmosis and arbo virus diseases. In addition, both faecal and throat swabs were inoculated onto monolayer cultures of Vero and Hep 2 cells and, intracere brally, into suckling mice: both systems were observed daily during a period of two weeks for signs of viral infection.

\section{RESULTS}

The acute sera from both children were posi tive for B 19 virus specific IgM antibody, confir ming a recent $B 19$ virus infection. There was no evidence of rubella, measles, infectious mono nucleosis, toxoplasmosis or arbovirus infection diseases in either child. One enterovirus isolate (probably coxsackie virus group A) was obtained by intracerebral mouse inoculation of a faecal suspension from one child.

\section{DISCUSSION}

A broad spectrum of aetiological agents in the Amazon region have been found to be asso. ciated with exanthematous illness. Apart from the frequent occurrence of rubella, measles, in fectious mononucleosis, toxoplasmosis and enteroviral infections, arboviruses may also give rise to febrile disease with erythematous macu lopapular rash. With respect to the latter viral agents, epidemics of Oropouche and Mayaro fe vers and Dengue (with rash being commonly seen) have been extensively reported in our re gion $^{13.14 .19}$.

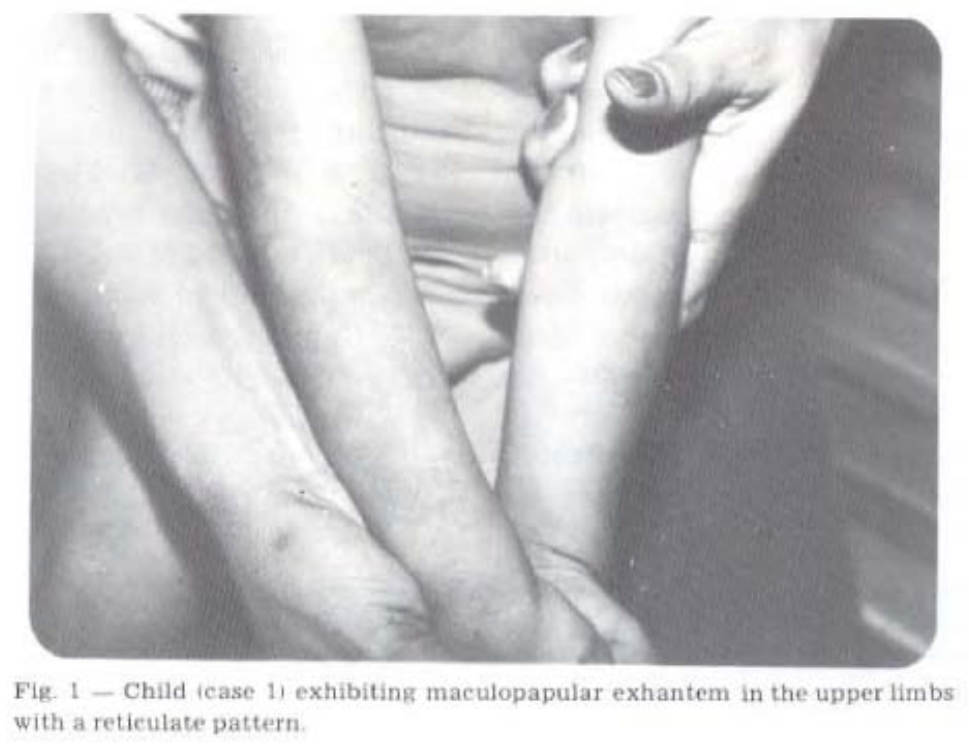


MiRANDA, M. F. R. de: LINHARES. A. C. \& SHIRLEY, J. A. - Fifth disease in children living in Belem, Brazil. Rev, Inst. Med. trop. S. Paulo, 31(5): 359 362, 1989

There have frequently been cases of "rube lla-like" illnesses in which all the above mentioned tests are consistently negative, and their aetiology still remains to be elucidated, particularly in children. It is possible that B 19 virus is responsible for a proportion of such undiagnosed cases.

The two patients from Belém, Brazil, exhibited clinical features which were compatible to those generally described for erythema infectio$\mathrm{sum}^{3.8 .16}$. Virological investigations of specimens obtained from these patients confirmed a recent $B 19$ virus infection as indicated by the presence of B 19 specific IgM antibody. We did isolate an enterovirus strain (probably coxsackie virus group A) from the faeces from one child but not from the other. This latter finding may not be of significance in the aetiology of the acute exanthematous disease in our cases, although such symptoms have been associated with the coxsackie virus group $\mathrm{A}^{11}$.

To our knowledge, this is the first time that both clinical and laboratory evidence have been obtained for the presence of "fifth disease" in Brazil. Based upon clinical evidence, one of us (MFRM) has recorded ten cases (Fig. 2) of erythema infectiosum in Belém from 1984 to March 1987 in both the Brazilian Air Force Hospital and his private clinic. All patients were children with ages ranging from two to eleven years exhibiting the classical "slapped cheek" appearance on face, an exanthem with reticulate pattern on limbs and/or trunk and, sometimes, low fever. With the exception of the two cases reported here, which were observed among brothers, the remaining eight had no known contact. Unfortu-

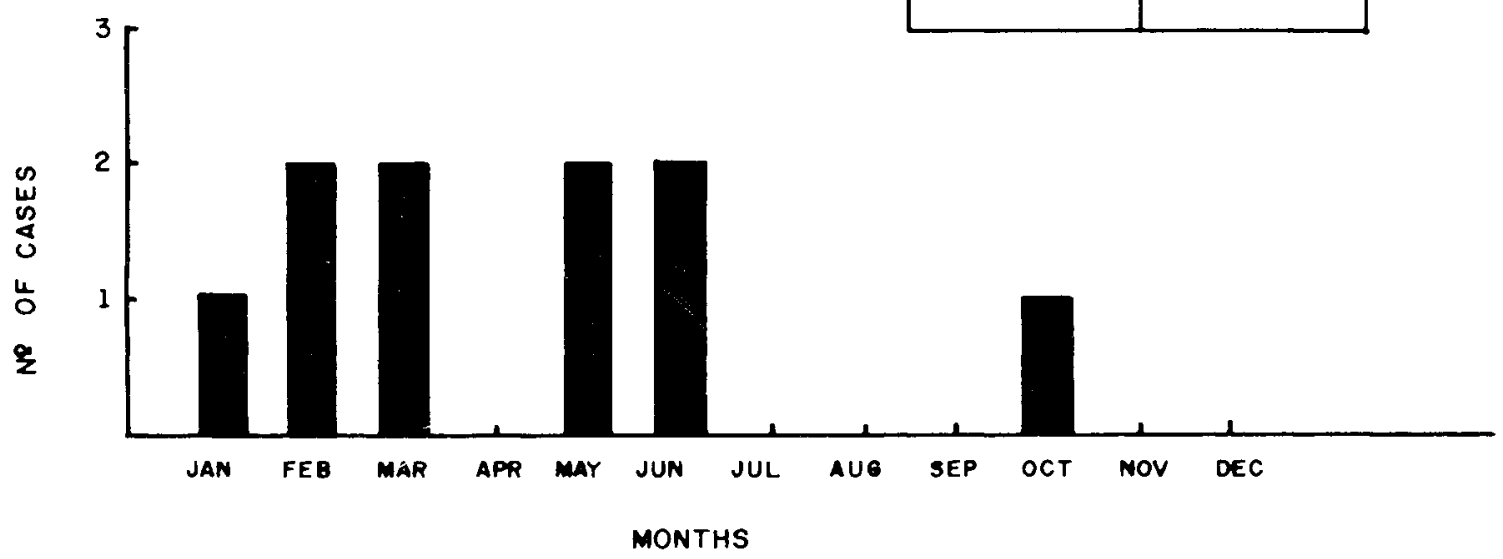

nately, sera from the remaining eight cases were not available for laboratory diagnosis of B 19 virus infection. Clinical evidence suggests that the disease occurs mainly during the first half of the year, when the highest rainfall and humidity are registered.

Experienced dermatologists in Belem sup pose that the disease must be of recent introduction in our region, as cases like those repor ted here have not been seen in the past.

Our preliminary findings indicate that "fifth disease" occurs in the Amazon region with a possible seasonal pattern. Further studies should be conducted in order to evaluate the public health importance of this disease. It is important that it should not be misdiagnosed as an "allergy", thus leading to the unwise use of steroids: this was seen in one patient of our series whose period of illness had been prolonged as a result of cortico-steroid therapy.

Since parvovirus infection of pregnant ani mals can lead to severe fetal abnormalities and may cause spontaneous abortion, there is a gro wing interest in the possibility that human parvo virus might harm the fetus or newborn. Human parvovirus has been shown to cross the placenta

\begin{tabular}{|l|c|}
\hline YEAR & $\begin{array}{c}\text { NR. OF } \\
\text { CASES }\end{array}$ \\
\hline 1984 & 1 \\
1985 & 5 \\
1986 & 1 \\
1987 & 3 \\
\hline TOTAL & 10 \\
\hline
\end{tabular}

Fig. 2 - Monthly distribution of cases with typical clinical features of erythema infectiosum. Belem. Brazil, 1984 to 1987. 
MIRANDA, M. F. R. de; LINHARES, A. C. \& SHIRLEY, J. A. - Fith disease in children living in Belém. Brazil. Rev. Inst. Med. trop. S. Paulo, 31(5): 359-362, 1989.

when infection occurs in pregnancy ${ }^{4}{ }^{10}$ and it has been suggested that $B 19$ virus infection cau ses fetal loss either by spontaneous abortion or still-birth ${ }^{12}$. However, there is no evidence so far that implicates B 19 virus with congenital de fects. Thus, human parvovirus B 19 infection should be considered as an alternative diagnosis to rubella, particularly in pregnant women whe re the latter infection may have serious consequences for the fetus.

\section{RESUMO}

\section{Quinta doença em erianças habitantes de Be- lém, Brasil}

Amostras de soro colhidas na fase aguda de doença exantemática, acomentendo duas crian ças, revelaram-se positivas quanto à presença de IgM especifica para o virus B 19 , através do método de rádio-imuno-ensaio por mecanis mo de captura. O primeiro paciente, um menino de dois anos, apresentou erupção cutánea com seis dias de duraçāo; o segundo foi uma menina de quatro anos de idade, irmá do primeiro paciente e que foi submetida a exame à mesma época em que se procedeu à avaliação clínica do irmào, e que exibia "rash" cutâneo que evo luía há três dias.

\section{ACKNOWLEDGEMENTS}

We thank Drs. Ronaldo B. de Freitas and Yvone G. Mendes for their valuable cooperation. Thanks are also due to Mrs. Margarete F. Garcia for typing the manuscript.

\section{REFERENCES}

1. ANDERSON, M. J.; DAVIES. I. R.: HODGSON. J.: JO NES. S. E.: MUTARZA. L.: PATTISON. J. L.: STROND C. E. \& WHITE. J. M. - Occurrence of infection with a parvovirus like agent in children with sickle cell anaemia during a two year period. J. clin. Path., 35: 744 749. 1982

2. ANDERSON, M. J.: LEWIS, E.: KIDD, I. M.: HALL. S M. \& COHEN, B. J. -.. An outbreak of ery thema infectiosum associated with human parvovirus infection. J. Hyg. (Lond.), 93: 85-93, 1984.

3. AZULAY. R. D. - Dermatologia. Rio de Janeiro. Guana bara Koogan. 1985, $364 \mathrm{p}$

4. BROWN. T.: ANAND. A.; RITCHIE, L. D.: CLEWLEY. J. P. \& REID. T. M. S. - Intrauterine parvovirús infection associated with hydrops fetalis. Jancet, 2: 1033 1034, 1984.

5. COHEN. B. J.: MORTIMER, P. P. \& PEREIRA, M. S. - Diagnostic assay with monoclonal antibodies for the human serum parvovirus-like virus (SPLV). J. Hyg. (Lond.), 91: 113:130. 1983

6. COSSART. Y. E.: CANT, B.: FIELD. A. M. \& WIDDOWS D. - Parvovirus-like particles in human sera. Lancet, 1 71.73. 1975

7. DUNCAN. J. R.: POTTER, C. G.: CAPPELLINI. M. D. KURTZ.J. B.: ANDERSON. M. J. \& WHETHERALL. D $\mathrm{J}$. - Aplastic crisis due to parvovirus infection in pyruvate kinase deficiency. Lancet, 2: 14 16, 1983

8. FITZPATRICK. T. B.: ISEN. A. Z.: WOLFF. K.: FREED BERG. I. M. \& AUSTEN, K. F. - Dermatology in general medicine. New York. McGraw Hill Book. 1979. 1944 p

9. KELLEHER, J. F.: LUBAN, N. L. C.: MORTIMER, P. P \& KAMIMURA. T. - Human serum "parvovirus": a spe cific cause of aplastic crisis in children with hereditary spherocytosis. J. Pediat., 102: 702 722. 1983

10. KNOTT. P. D.; WEPLY, G. A. C. \& ANDERSON. M. J - Serologically proven intrauterine infection with parvo virus. Brit. med. J., 289: 1660, 1984.

11. MELNICK, J. L. \& WENNER, H. A. - Enteroviruses. In LENNETTE. E. H. \& SCHMIDT. N. J. - DIAGNOSTIC PROCEDURES FOR VIRAL AND RICKETTSIAL IN FECTIONS 4. ed. New York, American Public Health As sociation. 1969 . p. 529.602 .

12. MORTIMER, P. P.: COHEN, B. J.: BUCKLEY, M. M.: CRADOCK WATSON. J. E.: RIDEHALGH. M. K. S.: BURKHARDT. F. \& SCHILT. U. - Human parvovirus and the fetus. Lancet, 2: 1012. 1985

13. Pinheiro. F. P. - Febre do Oropouche. J. bras. Med., 44: 46-62, 1983

14. PINHEIRO, F. P.: FREITAS, R. B.: TRAVASSOS DA ROSA, J. F.; GABBAY, Y. B.; MELLO, W. A. \& Le DUC, J. W. - An outbreak of Mayaro virus disease in Belterra. Brazil. Amer. J. trop. Med. Hyg., 30: 674 681, 1981

15. REID, D. M.; BROWN, T.: REID. T. M. S.: RENNIE. J A. N. \& EASYMOND, C. J. - Human parvovirus associa ted arthritis: a clinical and laboratory description. Lancet. 1: $422.424,1985$.

16. ROOK, A.; WILKINSON, D. S. \& EBLING, F. J. G. Textbook of dermatology. Oxford, Blackwell Scientific Publications. 1968. $1921 \mathrm{p}$

17. SERGEANT, G. R.: MASON, K.; TOPLEY. J. M.: SER GEANT. B. M.: PATTISON, J. R.: JONES. S. E. \& MO HAMMED. R. - Outbreak of aplastic crisis in sickle cell anaemia associated with parvovirus-like agent. Lancet, 2: $595-597,198$

18. SHNEERSON. J. M.; MORTIMER. P. P. \& VANDERVEL DE, G. M. - Febrile illness due to a parvovirus. Brit med. J., 11: 1580,1980

19. TRAVASSOS DA ROSA, A. P. A.; ROCHA. J. M.: SILVA. O. V. \& LINS. Z. C. -- Surto de dengue em Boa Vista. território de Roraima, Brasil. Bol. epidem. (Rio de J.), 14: 93, 95, 97, 100, 1982.

20. WHITE, D. G.: MORTIMER, P. P.: BLAKE, D. R.: WOOLF, A. D.: COHEN, B. J \& BACON, P. A. - Human parvovirus arthropathy. Lancet, 1: 419421,1985

Recebido para publicaçāo em 1341989 